\title{
Direct Operation of Methane Fueled Solid Oxide Fuel Cells with Ni Cermet Anode via Sn modification
}

\author{
Qi Yang, ${ }^{1}$ Jian Chen, ${ }^{3}$ Chunwen Sun,,${ }^{1,2 *}$ Liquan Chen, ${ }^{1}$
}

${ }^{1}$ Key Laboratory for Renewable Energy, Beijing Key Laboratory for New Energy Materials and Devices, Beijing National Laboratory for Condensed Matter Physics, Institute of Physics, Chinese Academy of Sciences, Beijing 100190, China

${ }^{2}$ Beijing Institute of Nanoenergy and Nanosystems, Chinese Academy of Sciences; National Center for Nanoscience and Technology (NCNST), Beijing 100083, China

${ }^{3}$ National Institute for Nanotechnology (NINT), National Research Council (NRC), Edmonton, Alberta T6G 2M9, Canada

${ }^{*}$ Corresponding author. Tel: +86-10-82854648, Fax: +86-10-82854648, Email: sunchunwen@ @inn.cas.cn, csun@iphy.ac.cn (C. Sun)

ABSTRACT: Traditional solid oxide fuel cells (SOFCs) with Ni cermet anode are not stable operating in $\mathrm{CH}_{4}$ due to carbon deposition. Here we report excellent long-term stability of the cell with Ni/SDC anode is achieved in $3 \% \mathrm{H}_{2} \mathrm{O}$ humidified $\mathrm{CH}_{4}$ in a temperature range of $700 \sim 800^{\circ} \mathrm{C}$ by addition of $1 \mathrm{wt} \% \mathrm{Sn}$ to the porous anode. The addition of a small amount of Sn does not compromise the electrochemical performance of the cell in humidified $\mathrm{H}_{2}$. For the $1 \% \mathrm{Sn}-\mathrm{Ni} / \mathrm{SDC}$ anode, the peak power density of the cell reaches $0.28 \mathrm{Wcm}^{-2}$ in $3 \% \mathrm{H}_{2} \mathrm{O}$ humidified $\mathrm{CH}_{4}$ and the current density decreases only by $30 \%$ after the cell is operated under a constant voltage of $0.8 \mathrm{~V}$ 
in humidified $\mathrm{CH}_{4}$ for 230 hours at $700^{\circ} \mathrm{C}$. The Ni and Sn mappings of the tested cell indicate that $\mathrm{Sn}$ is enriched on the anode surface and Sn-Ni intermetallics form. It is found that a critical process is essential to oxidize the impregnated $\mathrm{SnCl}_{2}$ into $\mathrm{SnO}_{2}$ at a temperature higher than $800^{\circ} \mathrm{C}$, hence metallic Sn can be obtained and consequently it further forms highly catalytic activity Sn-Ni intermetallics in $\mathrm{H}_{2}$. These results demonstrate that the addition of $1 \mathrm{wt} \% \mathrm{Sn}$ can significantly enhance the coking tolerance of the $\mathrm{Ni} / \mathrm{SDC}$ anode.

Keywords: solid oxide fuel cells, Ni cermet anode, Sn modification, direct oxidation of methane 


\section{Introduction}

There has been considerable interest in the direct operation of solid oxide fuel cells (SOFCs) with hydrocarbon fuels [1-11]. Unlike an internal reforming, directly electrochemical oxidation of hydrocarbon in SOFCs do not need to introduce a substantial amount of $\mathrm{H}_{2} \mathrm{O}, \mathrm{CO}_{2}$ or $\mathrm{O}_{2}$, which greatly simplifies the system and reduces the cost [12-13]. The most commonly used nickel/yttria-stabilized zirconia (Ni/YSZ) anodes have showed excellent performance in $\mathrm{H}_{2}$ fuel; however, there is serious carbon deposition when hydrocarbon fuels are used [1,2].

In recent years, great efforts have been devoted to develop alternative anodes to alleviate carbon deposition issue encountered in Ni-based cermets anode [3-10]. However, the long-term stability and catalytic activity of the proposed alternative anode materials so far are still not satisfactory yet when hydrocarbon fuels are used. Lee et al. have reported that the addition of $1 \mathrm{wt} \% \mathrm{Sn}$ to the traditional Ni/YSZ anode could decrease carbon deposition. They observed that a higher amount of Sn existed on the surface of anode [14]. Hyun et al. also demonstrated that Sn could increase the activation energy of methane pyrolysis and thus the carbon deposition rate is reduced [15]. However, their preparation method was relatively complex. Furthermore, Hill et al. [16] also found that the addition of Sn did not improve the carbon tolerance of the traditional $\mathrm{Ni}$ cermet anode when the $\mathrm{SnCl}_{2}$ infiltrating $\mathrm{NiO}$-YSZ composite anode was calcined at a lower temperature of $500^{\circ} \mathrm{C}$. Inspired by the above promising results and the idea of liquid tin/antimony anode for direct carbon SOFCs [17-19], herein, we prepared Sn-modified Ni/SDC cermet anode for SOFCs with methane fuel. The 
feasibility of the Sn-Ni/SDC as an anode material for methane-fueled SOFCs was investigated with a $\quad \mathrm{La}_{0.9} \mathrm{Sr}_{0.1} \mathrm{Ga}_{0.8} \mathrm{Mg}_{0.2} \mathrm{O}_{3-\delta} \quad$ (LSGM, $\quad 250 \mu \mathrm{m}$ thick) electrolyte-supported configuration with a composite cathode consisting of $\mathrm{Sr}_{0.95} \mathrm{Ce}_{0.05} \mathrm{CoO}_{3-\delta}$ and SDC (30wt\%). The phase, distribution and morphology of Sn was revealed by high angle annular dark field scanning transmission electron microscopy (HAADF STEM).

\section{Experimental}

Single cells were fabricated by a $\mathrm{La}_{0.9} \mathrm{Sr}_{0.1} \mathrm{Ga}_{0.8} \mathrm{Mg}_{0.2} \mathrm{O}_{3-\delta}$ (LSGM, >99\% dense) electrolyte-supported technique. LSGM electrolyte was prepared by uniaxially pressing a well-milled mixture of LSGM (PRAXAIR Inc) powder and 1wt $\%$ polyvinyl butyral (PVB), and then sintered at $1450^{\circ} \mathrm{C}$ for 10 hours [20]. A thin buffer layer of $\mathrm{La}_{0.4} \mathrm{Ce}_{0.6} \mathrm{O}_{2-\delta}$ (LDC) between the anode and the electrolyte was used to prevent cation migration between $\mathrm{NiO}$ and LSGM [21]. The NiO-Sm ${ }_{0.2} \mathrm{Ce}_{0.8} \mathrm{O}_{2-\delta}(\mathrm{SDC})$ composite anode (weight ratio of $\mathrm{NiO}: \mathrm{SDC}$ is $65: 35$ ) and $\mathrm{Sr}_{0.95} \mathrm{Ce}_{0.05} \mathrm{CoO}_{3}$ (SCCO)-SDC composite cathode (weight ratio of SCCO and SDC is 70:30) were both prepared by a screen-printing method and heated at $1200^{\circ} \mathrm{C}$ for 2 hours and $1050^{\circ} \mathrm{C}$ for 2 hours, respectively. $\mathrm{NiO}$ and SDC powders were synthesized by a glycine-nitrate combustion process [22]. SCCO powder was prepared by a sol-gel method [23]. Tin chloride $\left(\mathrm{SnCl}_{2} \cdot 2 \mathrm{H}_{2} \mathrm{O}\right)$ solution of ethyl alcohol was introduced into the anode by an impregnating method. The Sn loading was about $1 \mathrm{wt} \%$ with respect to the Ni content in the catalyst. Ag paste was used as a current collector on the anode side while $\mathrm{Pt}$ 
paste was used as a current collector on the cathode side. Before testing, the anode catalyst was calcined at $850^{\circ} \mathrm{C}$ in air for 1 hour to fully oxidize the $\mathrm{SnCl}_{2}$ to $\mathrm{SnO}_{2}$.

Since the literature reported that the addition of $\mathrm{Sn}$ did not enhance the carbon tolerance of the traditional $\mathrm{Ni}$ cermet anode when the $\mathrm{SnCl}_{2}$ infiltrating $\mathrm{NiO}-\mathrm{YSZ}$ anode was calcined at a lower temperature of $500^{\circ} \mathrm{C}$ [16]. To examine the existing phase and morphology of Sn for the anodes calcined at lower temperatures, another two cells were calcined at $800^{\circ} \mathrm{C}$ and $750^{\circ} \mathrm{C}$ in air respectively before reducing at $700^{\circ} \mathrm{C}$ in $3 \% \mathrm{H}_{2} \mathrm{O}$ humidified $\mathrm{H}_{2}$ for 2 hours. These three cells are hereafter referred to as Cell-850, Cell-800 and Cell-750, respectively.

The open circuit voltage (OCV) curves and current density-voltage curves were measured with an IM6 electrochemical workstation (ZAHNER, Germany) at the operating temperature range of $700^{\circ} \mathrm{C}$ to $800^{\circ} \mathrm{C}$. The cathode side was exposed to air and the anode side was exposed to $3 \% \mathrm{H}_{2} \mathrm{O}$ humidified hydrogen or $\mathrm{CH}_{4}$ at a flow rate of $100 \mathrm{mLmin}^{-1}$. Impedance spectra were measured at the open-circuit voltage (OCV) in a frequency range of $50 \mathrm{mHz}$ to $100 \mathrm{kHz}$ with an amplitude of $5 \mathrm{mV}$. The cell structure was analyzed by scanning electron microscope (SEM, Hitachi-S4800). The existing state and the distribution of Sn were analyzed by elemental mapping and the selected area electron diffraction (SAED) with JEM 2200FS. The accelerating voltage is $200 \mathrm{kV}$.

\section{Results and Discussion}

Fig. 1a shows the cross-sectional SEM image of the $1 \mathrm{wt} \% \mathrm{Sn}-\mathrm{Ni} / \mathrm{SDC}$ single cell. 
The cell consists of a $\mathrm{SnCl}_{2}$ solution of ethyl alcohol infiltrating NiO-SDC composite anode, a LDC buffer layer, a LSGM electrolyte and a SCCO-SDC composite cathode. The thicknesses of the anode and cathode are about $35 \mu \mathrm{m}$, and the thickness of the electrolyte is about $250 \mu \mathrm{m}$. It can be seen that the four layers are well bonded. The SEM images of the porous anode and cathode are shown in Fig. 1b and Fig. 1c, respectively.

Fig. 2 shows the cell voltages and power densities as a function of current density for cells with $1 \mathrm{wt} \% \mathrm{Sn}-\mathrm{Ni} / \mathrm{SDC}$ and pristine $\mathrm{Ni} / \mathrm{SDC}$ as anodes respectively at different temperatures in $3 \% \mathrm{H}_{2} \mathrm{O}$ humidified $\mathrm{H}_{2}$. As shown in Fig. 2a, the peak power density of the cell with $1 \mathrm{wt} \% \mathrm{Sn}-\mathrm{Ni} / \mathrm{SDC}$ anode reaches $1.16 \mathrm{Wcm}^{-2}$ at $800^{\circ} \mathrm{C}$, $0.77 \mathrm{Wcm}^{-2}$ at $750^{\circ} \mathrm{C}$ and $0.58 \mathrm{Wcm}^{-2}$ at $700^{\circ} \mathrm{C}$ in humidified $\mathrm{H}_{2}$. These values are close to those of the cells with the pristine $\mathrm{Ni} / \mathrm{SDC}$ anode, i.e., $1.20 \mathrm{Wcm}^{-2}$ at $800^{\circ} \mathrm{C}$, $0.83 \mathrm{Wcm}^{-2}$ at $750^{\circ} \mathrm{C}$ and $0.59 \mathrm{Wcm}^{-2}$ at $700^{\circ} \mathrm{C}$, as shown in Fig. 2 b. The durability of both cells were tested in humidified $\mathrm{H}_{2}$ at $0.8 \mathrm{~V}$ for $100 \mathrm{~h}$ at $700^{\circ} \mathrm{C}$ (Fig. 2c). The cell with $1 \mathrm{wt} \% \mathrm{Sn}-\mathrm{Ni} / \mathrm{SDC}$ anode has a similar performance to that of the cell with the pristine Ni/SDC cell. These results indicate that the addition of a small amount of Sn does not compromise the cell performance with humidified $\mathrm{H}_{2}$ as the fuel at the temperatures studied. The peak power densities of the cell with $1 \mathrm{wt} \% \mathrm{Sn}-\mathrm{Ni} / \mathrm{SDC}$ anode reach $0.64,0.39$ and $0.28 \mathrm{Wcm}^{-2}$ at 800,750 and $700^{\circ} \mathrm{C}$, respectively, in humidified $\mathrm{CH}_{4}$, as shown in Fig. 3. It indicates that the cell with 1 wt\%Sn-Ni/SDC shows excellent performance operating in humidified $\mathrm{CH}_{4}$. Fig. 4 shows the OCV change as a function of time for the cell with $1 \mathrm{wt} \% \mathrm{Sn}-\mathrm{Ni} / \mathrm{SDC}$ anode and the pristine 
$\mathrm{Ni} / \mathrm{SDC}$ anode when the fuel was switched from humidified $\mathrm{H}_{2}$ to $\mathrm{CH}_{4}$ at $700^{\circ} \mathrm{C}$. It can be seen that the OCV of the cell with $1 \mathrm{wt} \% \mathrm{Sn}-\mathrm{Ni} / \mathrm{SDC}$ anode keep stable in two hours while the OCV of the cell without Sn modification drops dramatically. This result unequivocally indicates that the addition of $1 \mathrm{wt} \% \mathrm{Sn}$ to the Ni cermet anode can enhance the coking tolerance.

Long-term stability of the $1 \mathrm{wt} \% \mathrm{Sn}-\mathrm{Ni} / \mathrm{SDC}$ anode cell at $0.8 \mathrm{~V}$ and $700^{\circ} \mathrm{C}$ in $3 \% \mathrm{H}_{2} \mathrm{O}$ humidified $\mathrm{CH}_{4}$ is shown in Fig. 5. The decrease of current density is less than thirty percent after operating for 230 hours. However, for the Sn-free Ni/SDC anode cell, the current density of the cells quickly dropped below $0.1 \mathrm{Acm}^{-2}$ when the fuel was switched from humidified $\mathrm{H}_{2}$ to $\mathrm{CH}_{4}$ (see Fig. 6). Therefore, we conclude that for the Cell-850 with addition of $1 \mathrm{wt} \% \mathrm{Sn}$ to the anode dramatically improves the Ni cermet anode stability in humidified $\mathrm{CH}_{4}$.

To gain insights into the nature of the active component of anode for the $\mathrm{CH}_{4}$ electro-oxidation reaction, HAADF STEM analysis was conducted on the anode after long-term stability testing. Fig. 7a shows the HAADF STEM image of the 1 wt $\%$ Sn-Ni/SDC anode after the long-term stability test. The inset shows the convergent nano-beam diffraction (CBED) pattern of the particle arrowed. It can be indexed as $\mathrm{Ni}_{3} \mathrm{Sn}$. The bright field (BF) STEM image and the corresponding elemental mapping are shown in Fig. 7b. Besides elemental mappings, we also picked up some nanoparticles for further energy dispersive spectrometry (EDS) analysis, as shown in Figs. 7d f. For comparison, we also show the EDS spectrum collected on the overall mapping region when mapping was performing (Fig. 7g). Apparently, all 
the analyzed particles are rich in Sn. This is consistent with the EDS mapping results. All the above results indicate that $\mathrm{Sn}$ enrichment happens by forming $\mathrm{Sn}-\mathrm{Ni}$ intermetallics. Among them, $\mathrm{Ni}_{3} \mathrm{Sn}$ is one of the highly active catalysts for hydrocarbon oxidation [24-26]. The formed Sn-Ni intermetallics nanoparticles block the active step sites of $\mathrm{Ni}$ and reduce the size of active $\mathrm{Ni}$ ensembles, which will mitigate the coke formation [27]. Moreover, the formation of hydroxyl groups from water activation is essential for the removal of deposited carbon from the anode surface [28]. In the presence of Sn-Ni intermetallics, the Ni cermet anode tends to absorb more water due to the oxophilic nature of $\mathrm{Sn}$ and the dissociation of $\mathrm{H}_{2} \mathrm{O}$ happens more easily. Thus, the coking is suppressed significantly. Actually, $\mathrm{Sn}$ is one of oxophilic elements, which has been used to effectively reduce the serious $\mathrm{CO}$ poisoning at the anode of the Pt catalyst in direct methanol fuel cells (DMFCs) [29].

In order to examine whether the infiltrated $\mathrm{SnCl}_{2}$ has to be oxidized to $\mathrm{SnO}_{2}$ at above $800^{\circ} \mathrm{C}$ in air and subsequently forming highly active $\mathrm{Sn}-\mathrm{Ni}$ intermetallics in $\mathrm{H}_{2}$, another two cells were calcined at $800^{\circ} \mathrm{C}$ and $750^{\circ} \mathrm{C}$ in air respectively before reducing at $700^{\circ} \mathrm{C}$ in $3 \% \mathrm{H}_{2} \mathrm{O}$ humidified $\mathrm{H}_{2}$ for 2 hours. The durability of the cells operating at a constant voltage of $0.8 \mathrm{~V}$ at $700^{\circ} \mathrm{C}$ in wet $\mathrm{CH}_{4}$ is shown in Fig. 8. The Cell-800 shows much better durability than that of the Cell-750, which indicates that $\mathrm{SnCl}_{2}$ can not been oxidized completely into $\mathrm{SnO}_{2}$ in air at lower temperature. The HAADF STEM image of the anode of the Cell-750 was collected after the cell was cooled down to room temperature in dry $\mathrm{N}_{2}$, as shown in Fig. 9a. In this case, we found that Ni and Sn distributed homogenously on the surface of the Ni cermet, no 
obvious Sn enrichment was observed. We also conducted nano CBED on a similar area in the same sample. Fig. $9 \mathrm{~b}$ shows the diffraction patterns. Indexation of the patterns A and B suggests that the corresponding particles are both metallic Ni. The zone axis of particle A is [011] while that for particle B is [-112]. Because the particle with pattern $\mathrm{C}$ is not at the edge of the sample and it is overlapped with other particles, we obtain a composite pattern. However, from the indicated indexation, we can conclude that the reflections belong to metallic Ni. All the CBED results provide extra evidence that there is no intermetallic phase formed between $\mathrm{Ni}$ and $\mathrm{Sn}$ for this sample. Therefore, it suggests that $\mathrm{SnCl}_{2}$ can be oxidized more completely into $\mathrm{SnO}_{2}$ in air for 1 hour only at a calcination temperature of above $800^{\circ} \mathrm{C}$. Then it can be reduced to metallic $\mathrm{Sn}$ subsequently and form highly active $\mathrm{Sn}-\mathrm{Ni}$ intermetallics in $\mathrm{H}_{2}$. Therefore, the appropriate procedures to be used for the anode preparation are as follows. Firstly, the $\mathrm{SnCl}_{2}$-inflitrated cell is calcined at $850^{\circ} \mathrm{C}$ in air for 1 hour to fully oxidize the $\mathrm{SnCl}_{2}$ to $\mathrm{SnO}_{2}$, then the anode was reduced at $700^{\circ} \mathrm{C}$ in $3 \% \mathrm{H}_{2} \mathrm{O}$ humidified $\mathrm{H}_{2}$ for 2 hours.

\section{Conclusion}

In this study, we fabricated $\mathrm{Sn}$ modified $\mathrm{Ni} / \mathrm{SDC}$ cermet anode cell by infiltrating $\mathrm{SnCl}_{2}$ solution of ethyl alcohol into the porous $\mathrm{Ni}$ cermet anode. The addition of a small amount of Sn (1wt\%) in the Cell-850 does not compromise the electrochemical performance in humidified $\mathrm{H}_{2}$. Stability tests reveal that the Cell-850 with $1 \mathrm{wt} \% \mathrm{Sn}-\mathrm{Ni} / \mathrm{SDC}$ anode is better than the cell with $\mathrm{Sn}-$ free Ni/SDC anode in humidified $\mathrm{CH}_{4}$ at $700^{\circ} \mathrm{C}$. The HAADF STEM image of the tested cell shows that the 
incorporation of a small amount of $\mathrm{Sn}$ into the surface of $\mathrm{Ni}$ cermet facilitates the formation of highly active $\mathrm{Sn}-\mathrm{Ni}$ intermetallics, and offers exceptional long-term stability without coking on operating with a humidified methane fuel. We also find that the infiltrated $\mathrm{SnCl}_{2}$ has to be oxidized to $\mathrm{SnO}_{2}$ at above $800^{\circ} \mathrm{C}$ in air for 1 hour for the purpose of being reduced to metallic Sn. Then the metallic Sn reacts with Ni to form highly active $\mathrm{Sn}-\mathrm{Ni}$ intermetallics in $\mathrm{H}_{2}$.

\section{ACKNOWLEDGMENT}

This work is financially supported by the National Science Foundation of China (NSFC) (Grant Nos. 51372271, 51172275) and the National Key Basic Research Program of China (Grant No. 2012CB215402).

\section{REFERENCES}

[1] A. Atkinson, S. Barnett, R.J. Gorte, J.T.S. Irvines, A.J. McEvoy, M. Mogensen, S.C. Singhal, J. Vohs, Advanced anodes for high-temperature fuel cells, Nat Mater. 3 (2004) 17-27.

[2] C.W. Sun, U. Stimming, Recent anode advances in solid oxide fuel cells, J. Power Sources 171 (2007) 247-260.

[3] Y. Huang, R.I. Dass, Z. Xing, J.B. Goodenough, Double perovskites as anode materials for solid-oxide fuel cells, Science 312 (2006) 254-257.

[4] T.H. Shin, S. Ida, T. Ishihara, Doped $\mathrm{CeO}_{2}-\mathrm{LaFeO}_{3}$ composite oxide as an active anode for direct hydrocarbon-type solid oxide fuel cells, J. Am. Chem. Soc. 133 
(2011) 19399-19407.

[5] S. Tao, J.T.S. Irvine, A redox-stable efficient anode for solid oxide fuel cells. Nat. Mater. 2 (2003) 320-323.

[6] J.C. Ruiz-Morales, J. Canales-Vázquez, C. Savaniu, D. Marrero-López, W. Zhou, J.T.S. Irvine, Disruption of extended defects in solid oxide fuel cell anodes for methane oxidation, Nature 439 (2006) 568-571.

[7] L. Yang, S. Wang, K. Blinn, M. Liu, Z. Liu, Z. Cheng, M. Liu, Enhanced sulfur and coking tolerance of a mixed ion conductor for SOFCs: $\mathrm{BaZr}_{0.1} \mathrm{Ce}_{0.7} \mathrm{Y}_{0.2-\mathrm{x}} \mathrm{Yb}_{\mathrm{x}} \mathrm{O}_{3-\delta}$, Science 326 (2009) 126-129.

[8] C.H. Yang, J. Li, Y. Lin, J. Liu, F.L. Chen, M.L. Liu, In situ fabrication of CoFe alloy nanoparticles structured $\left(\operatorname{Pr}_{0.4} \mathrm{Sr}_{0.6}\right)_{3}\left(\mathrm{Fe}_{0.85} \mathrm{Nb}_{0.15}\right)_{2} \mathrm{O}_{7}$ ceramic anode for direct hydrocarbon solid oxide fuel cells, Nano Energy 11 (2015)704-710.

[9] C.H. Yang, Z.B. Yang, C. Jin, G. Xiao, F.L. Chen, M.F. Han, Sulfur-tolerant redox-reversible anode material for direct hydrocarbon solid oxide fuel cells, Adv. Mater. 24 (2012) 1439-1443.

[10] W. Yang, C. Zhu, Z. Ma, C. Sun, L. Chen, Y. Chen, $\mathrm{MoO}_{3}$ nanorods/ $/ \mathrm{Fe}_{2}\left(\mathrm{MoO}_{4}\right)_{3}$ nanoparticles composite anode for solid oxide fuel cells, Int. J. Hydro. Energy 39 (2014) 14411-14415.

[11] L. Yang, Y. Choi, W. Qin, H. Chen, K. Blinn, M. Liu, J. Bai, T.A. Tyson, M. Liu, Promotion of water-mediated carbon removal by nanostructured barium oxide/nickel interfaces in solid oxide fuel cells, Nat. Commun. 2 (2011) 357.

[12] Y. Lin, Z. Zhan, J. Liu, S.A. Barnett, Direct operation of solid oxide fuel cells 
with methane fuel, Solid State Ionics 176 (2005) 1827-1835.

[13] L. Liu, Q. Yang, W. Yang, X. Qi, C.W. Sun, L.Q. Chen, Li/Na Modified Ni-SDC Anode for Methane-fueled Solid Oxide Fuel Cells, ECS Transactions 68 (2015) 1403-1409.

[14] H. Kan, H. Lee, Sn-doped Ni/YSZ anode catalysts with enhanced carbon deposition resistance for an intermediate temperature SOFC, Appl. Catal. B: Environ. 97 (2010) 108-114.

[15] J. Myung, S.D. Kim, T.H. Shin, D. Lee, J.T.S. Irvine, J. Moon, S.H. Hyun, Nano-composite structural Ni-Sn alloy anodes for high performance and surability of direct methane-fueled SOFCs, J. Mater. Chem. A 3 (2015) 13801-13806.

[16] A. Singh, J.M. Hill, Carbon tolerance, electrochemical performance and stability of solid oxide fuel cells with $\mathrm{Ni} / \mathrm{yttria}$ stabilized zirconia anodes impregnated with Sn and operated with methane, J. Power Sources 214 (2012) 185-194.

[17] H. Abernathy, R. Gemmen, K. Gerdes, M. Koslowske, T. Tao, Basic properties of a liquid anode solid oxide fuel cell, J. Power Sources 196 (2011) 4564-4572.

[18] S. Khurana, M. LaBarbera, M.V. Fedkin, S.N. Lvov, H. Abernathy, K. Gerdes, Performance evaluation of a liquid tin anode solid oxide fuel cell operating under hydrogen, argon and coal, J. Power Sources 274 (2015) 1049-1054.

[19] H. Wang, T. Cao, Y. Shi, N. Cai, W. Yuan, Liquid antimony anode direct acarbon fuel cell fueled with mass-produced de-ash coal, Energy 75 (2014) 555-559.

[20] K. Huang, J. Wan, J.B. Goodenough, Increasing power density of LSGM-based solid oxide fuel cells using new anode materials. J. Electrochem. Soc. 148 (2001) 
A788-794.

[21] Y.H. Huang, R.I. Dass, Z.L. Xing, J.B. Goodenough, Double perovskites as anode materials for solid-oxide fuel cells. Science 312 (2006) 254-257.

[22] R.R. Peng, C.R. Xia, Q.X. Fu, G.Y. Meng, D.K. Peng, Sintering and electrical properties of $\left(\mathrm{CeO}_{2}\right)_{0.8}\left(\mathrm{Sm}_{2} \mathrm{O}_{3}\right)_{0.1}$ powders prepared by glycine-nitrate process. Mater. Lett. 56 (2002) 1043-1047.

[23] W. Yang, T. Hong, S. Li, Z.H. Ma, C.W. Sun, C.R. Xia, L.Q. Chen, Perovskite Sr1-xCexCoO3-delta $(0.05<=\mathrm{x}<=0.15)$ as Superior Cathodes for Intermediate Temperature Solid Oxide Fuel Cells, ACS Appl. Mater.Interfaces. 5 (2013) $1143-1148$

[24] F. Xie, X. Chu, H. Hu, M. Qiao, S. Yan, Y. Zhu, H. He, K. Fan, H. Li, B. Zong, X. Zhang, Characterization and catalytic properties of Sn-modified rapidly quenched skeletal $\mathrm{Ni}$ catalysts in aqueous-phase reforming of ethylene glycol, J. Catal. 241 (2006) 211-220.

[25] J.W. Shabaker, D.A. Simonetti, R.D. Cortright, J.A. Dumesic, Sn-modified Ni catalysts for aqueous-phase reforming: Characterization and deactivation studies, J. Catal. 231 (2005) 67-76.

[26] E. Nikolla, J. Schwank, S. Linic, Measuring and relating the electronic structures of nonmodel supported catalytic materials to their performance, J. Am. Chem. Soc. 131 (2009) 2747-2754.

[27] N.M. Galea, D. Knapp, T. Ziegler, Density functional theory studies of methane dissociation on anode catalysts in solid-oxide fuel cells: suggestions for cok 
reduction, J. Catal. 247 (2007) 20-33.

[28] H. Zhu, R.J. Kee, V.M. Janardhanan, O. Deutschmann, D.G. Goodwin, Modeling elementary heterogeneous chemistry and electrochemistry in solid-oxide fuel cells, J. Electrochem. Soc. 152 (2005) A2427-2420.

[29] G. Stalnionis, L. Tamasauskaite-Tamasiunaite, V. Pautieniene, A. Sudavicius, A. Jusys, Modification of a Pt surface by spontaneous $\mathrm{Sn}$ deposition for electrocatalytic applications, J. Solid State Electrochem. 8 (2004) 892-899.

\section{Figure Captions}

Fig. 1. SEM images of the (a) cross-section of the cell, (b) anode surface and (c) cathode surface of the $1 \mathrm{wt} \% \mathrm{Sn}-\mathrm{NiO} / \mathrm{SDC}$ cell.

Fig. 2. Cell voltages and power densities as a function of current density for cells with (a) $1 \mathrm{wt} \% \mathrm{Sn}-\mathrm{Ni} / \mathrm{SDC}$ anode and (b) pristine $\mathrm{Ni} / \mathrm{SDC}$ anode operating at different temperatures in $3 \%$ $\mathrm{H}_{2} \mathrm{O}$ humidified $\mathrm{H}_{2}$, (c) Long-term stability of both cells tested at $700^{\circ} \mathrm{C}$ in $3 \% \mathrm{H}_{2} \mathrm{O}$ humidified $\mathrm{H}_{2}$ at $0.8 \mathrm{~V}$ for $100 \mathrm{~h}$. Stationary air was used as oxidant in all cases.

Fig. 3. Cell voltages and current power densities as a function of current density for the cell with $1 \mathrm{wt} \% \mathrm{Sn}-\mathrm{Ni} / \mathrm{SDC}$ as anode at different temperatures in humidified $\mathrm{CH}_{4}$

Fig. 4. Open-circuit voltage (OCV) change as a function of time for the cell with $1 \mathrm{wt} \% \mathrm{Sn}-\mathrm{Ni} / \mathrm{SDC}$ anode and pristine Ni/SDC anode when the fuel was switched from humidified $\mathrm{H}_{2}$ to $\mathrm{CH}_{4}$ at $700^{\circ} \mathrm{C}$.

Fig. 5. Long-term stability of the cell with $1 \mathrm{wt} \% \mathrm{Sn}-\mathrm{Ni} / \mathrm{SDC}$ as anode operating at a constant voltage of $0.8 \mathrm{~V}$ at $700^{\circ} \mathrm{C}$ with $3 \% \mathrm{H}_{2} \mathrm{O}$ humidified $\mathrm{CH}_{4}$ as fuel and stationary air as oxidant.

Fig. 6. Long-term stability of the cell with pure $\mathrm{Ni} / \mathrm{SDC}$ as anode under a constant voltage 
discharge at $0.8 \mathrm{~V}$ and $700^{\circ} \mathrm{C}$ when the fuel was switched from humidified $\mathrm{H}_{2}$ to $\mathrm{CH}_{4}$; in the first two hours, the fuel was humidified $\mathrm{H}_{2}$ and then it was switched to wet $\mathrm{CH}_{4}$. The red arrow indicates the point where the fuel was switched from the humidified $\mathrm{H}_{2}$ to $\mathrm{CH}_{4}$.

Fig. 7. (a) HAADF STEM image, (b) the bright field (BF) STEM image and the corresponding element mappings, and (c) ADF image of the $1 \mathrm{wt} \% \mathrm{Sn}-\mathrm{Ni} / \mathrm{SDC}$ cell after the long-term stability test, (d g) EDS of spots are indicated by arrows in Fig. c, (g) the EDS spectrum collected on overall mapping region when mapping was performing.

Fig. 8. The durability of the Cell- 750 and Cell- 800 operating at a constant voltage of $0.8 \mathrm{~V}$ at $700^{\circ} \mathrm{C}$ with $3 \% \mathrm{H}_{2} \mathrm{O}$ humidified $\mathrm{CH}_{4}$ as fuel and stationary air as oxidant.

Fig. 9. (a) The HAADF STEM image and the corresponding elemental mapping of the 1wt\%Sn-Ni/SDC anode of Cell-750; (b) ADF image and CBED patterns of the indicated particles in the same cell sample. 


\section{Graphical Abstract}

Excellent long-term stability of the cells with $\mathrm{Ni} / \mathrm{SDC}$ anode is achieved in $3 \% \mathrm{H}_{2} \mathrm{O}$ humidified

$\mathrm{CH}_{4}$ in a temperature range of $700 \sim 800^{\circ} \mathrm{C}$ by addition of $1 \mathrm{wt} \% \mathrm{Sn}$ to the porous anode calcined at $850^{\circ} \mathrm{C}$ in air for 1 hour before reducing in wet $\mathrm{H}_{2}$.

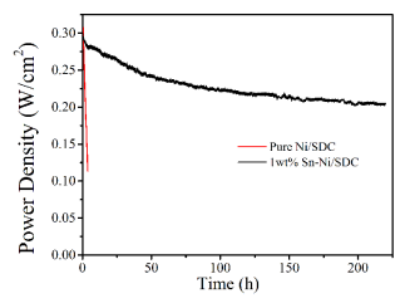




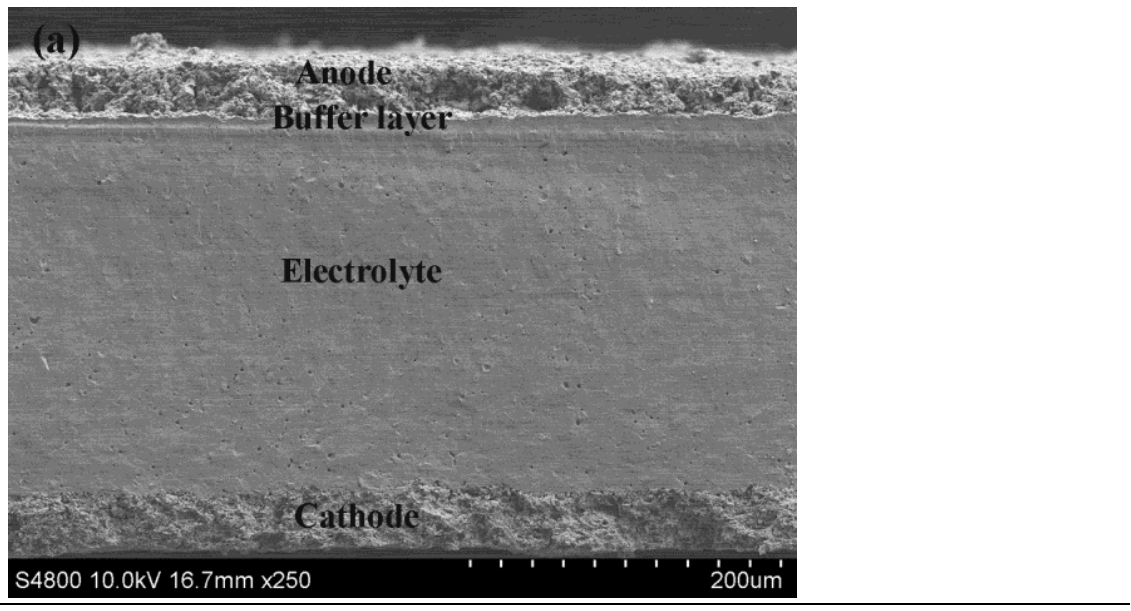




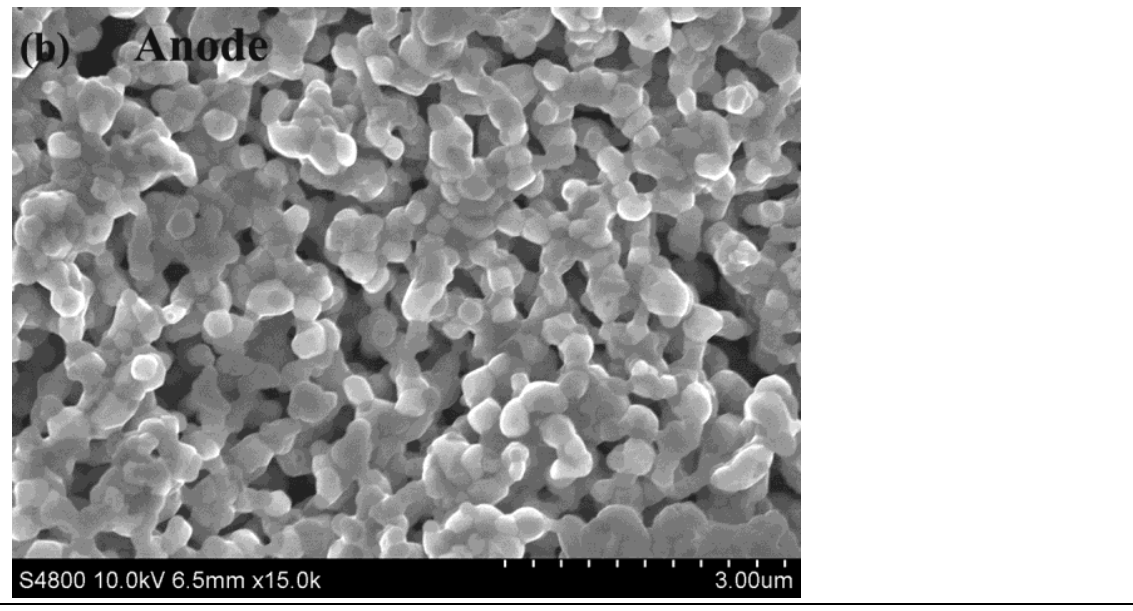




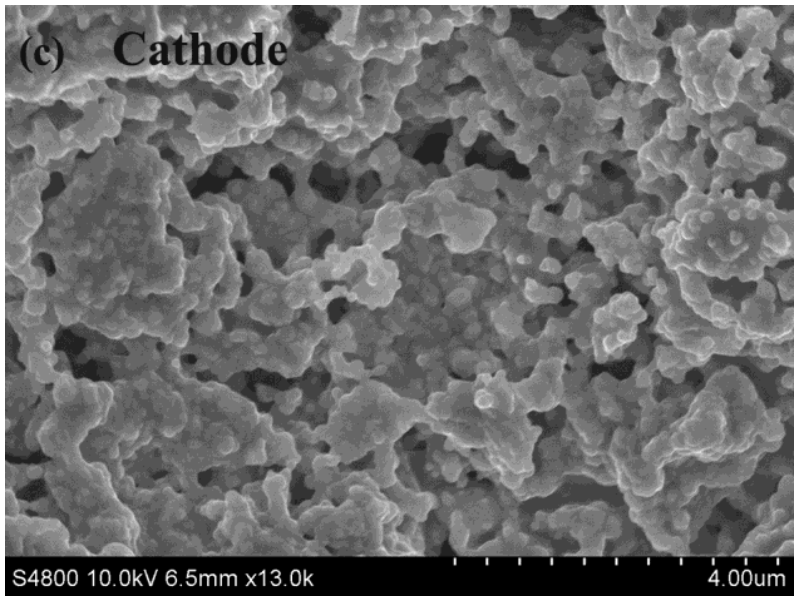




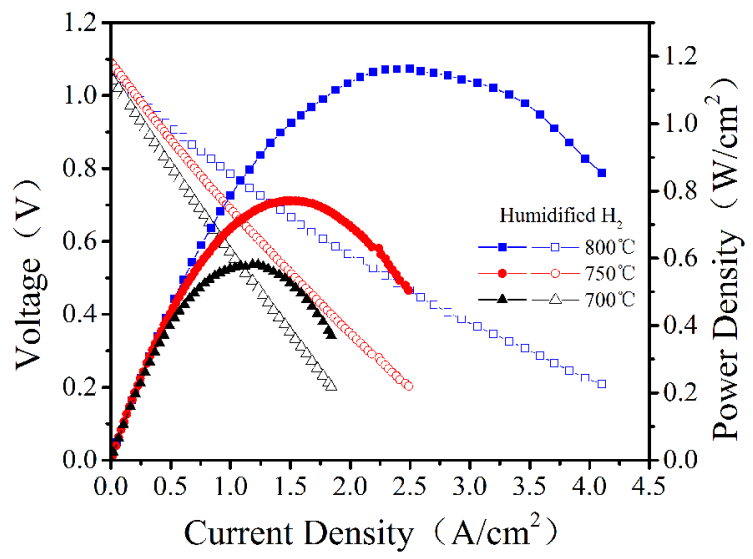

20 


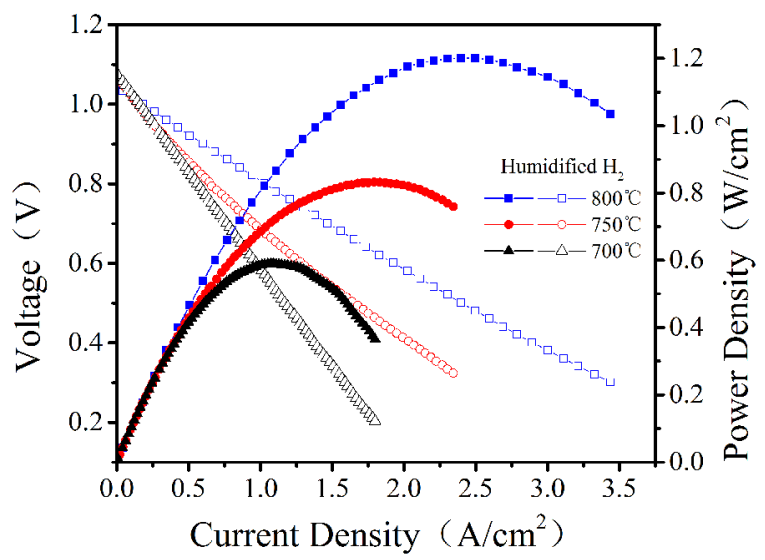




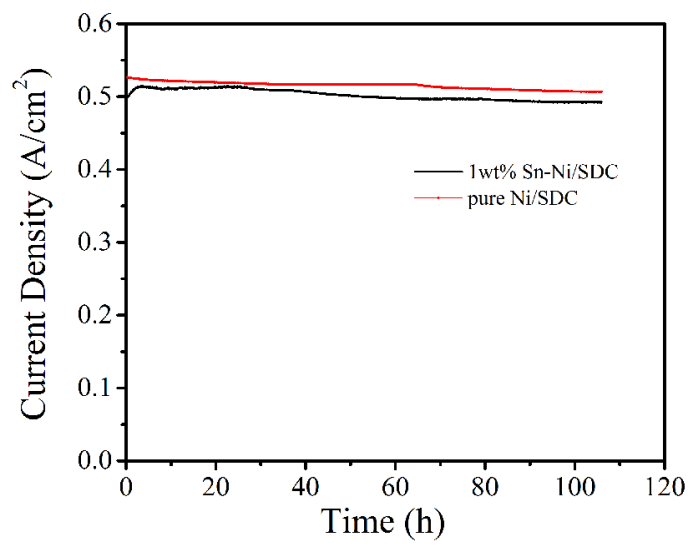




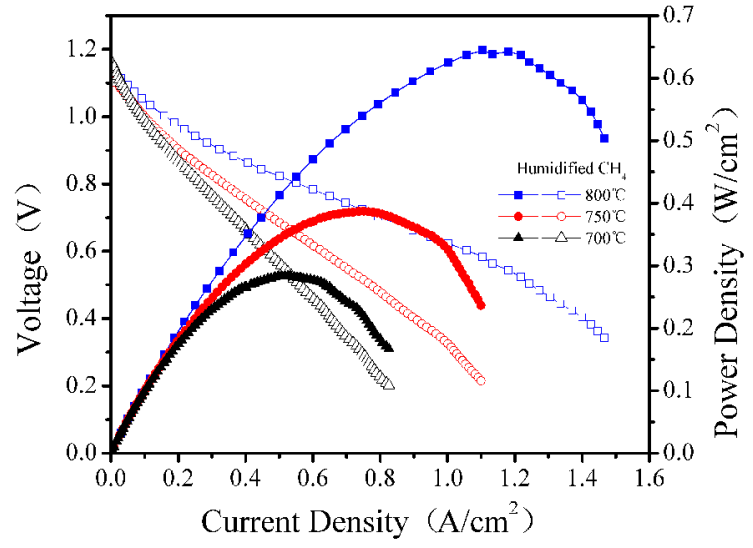




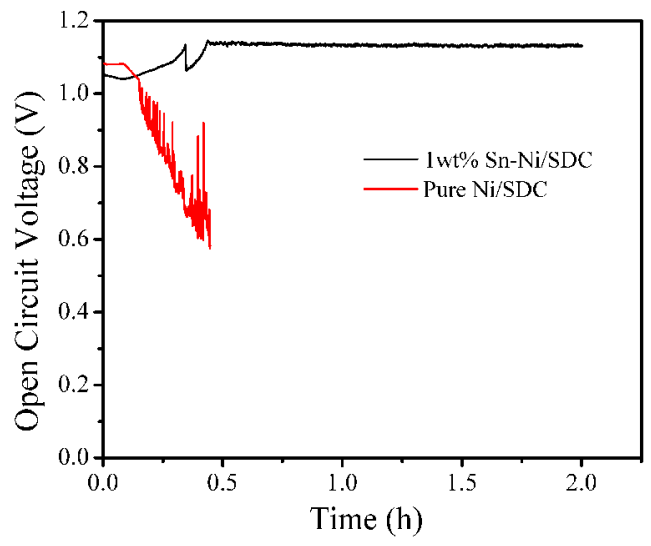




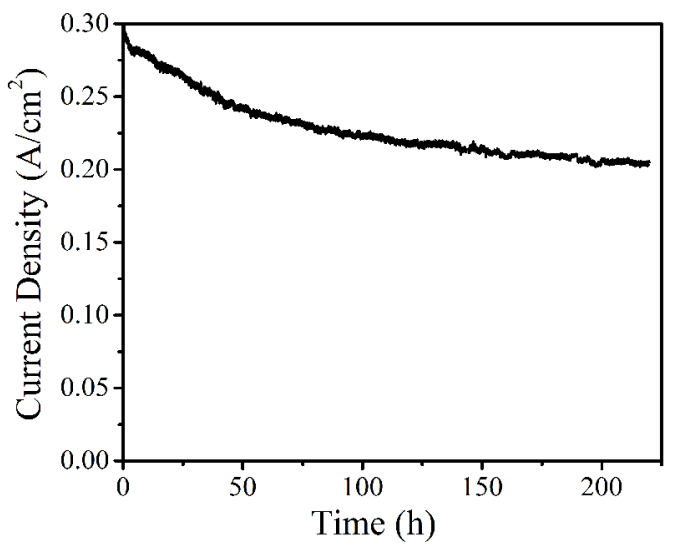




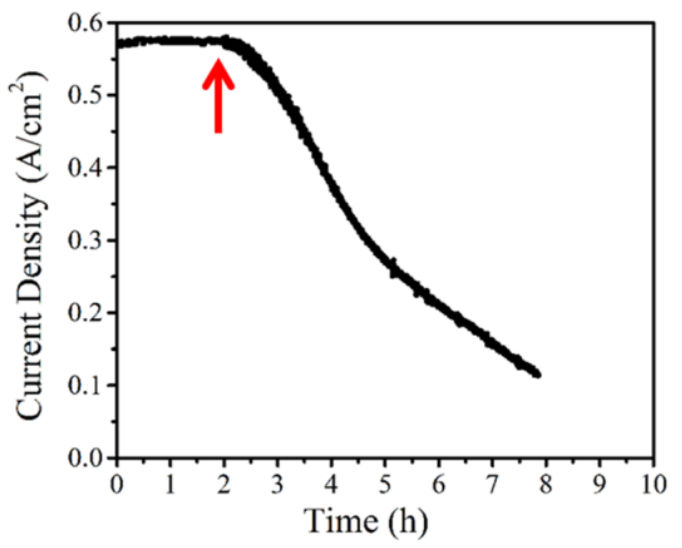




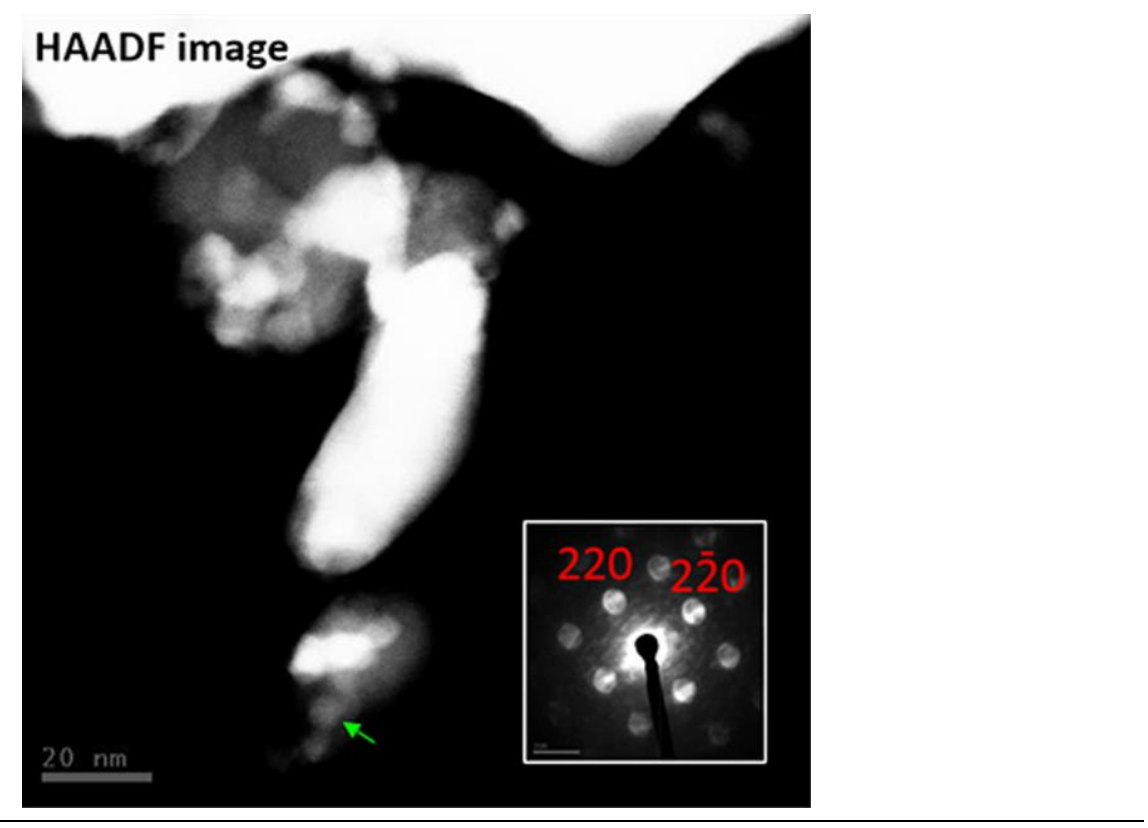



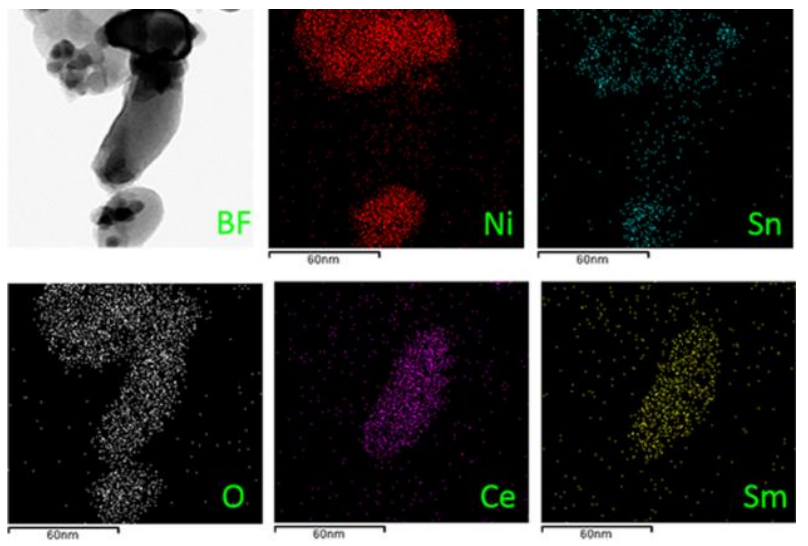


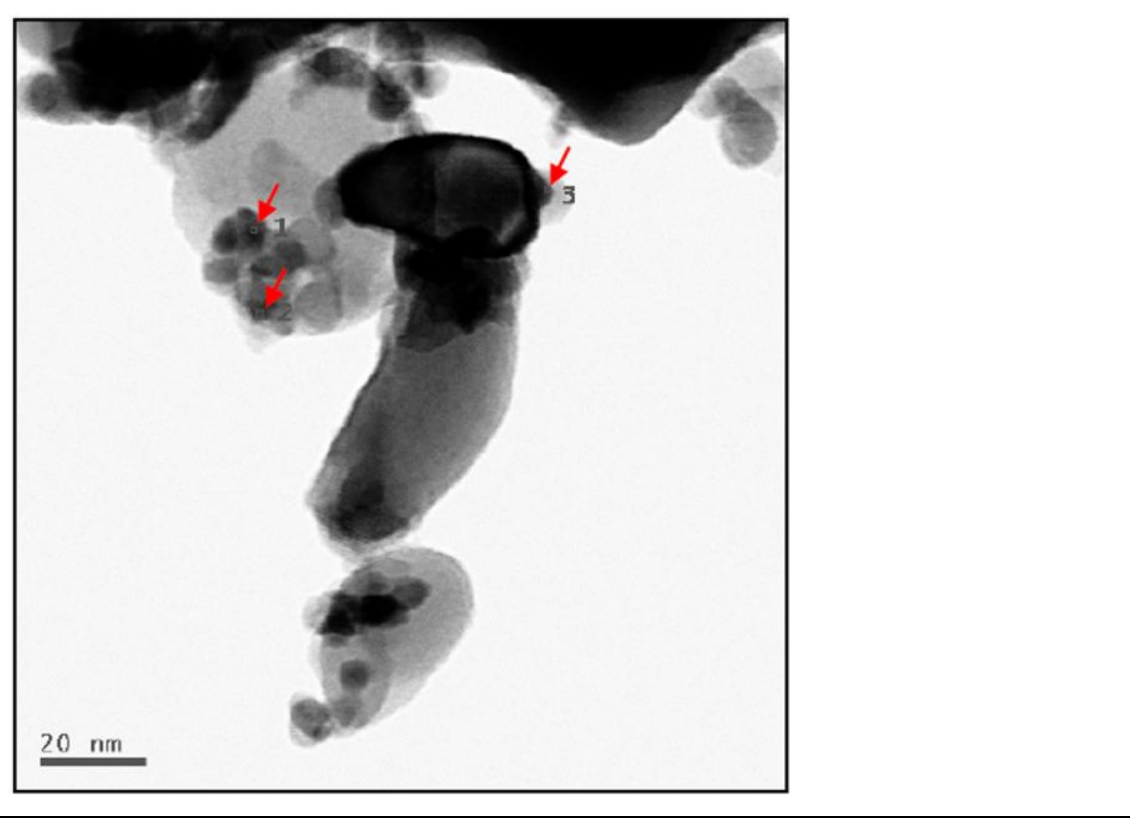




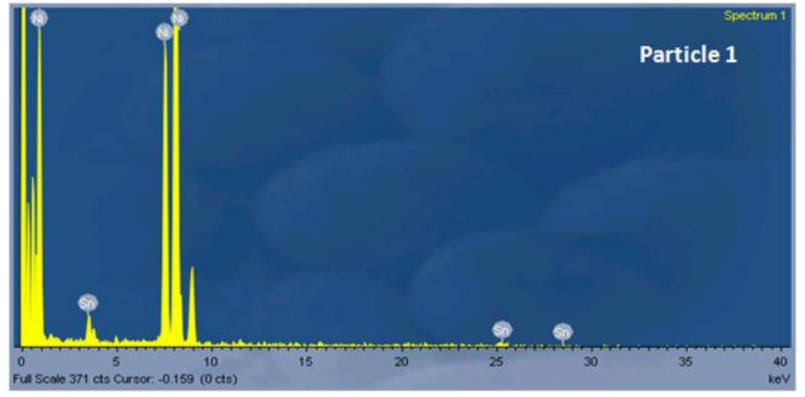




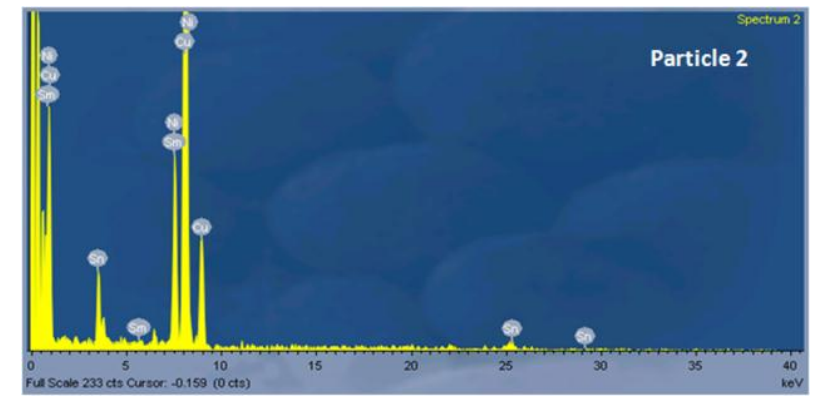




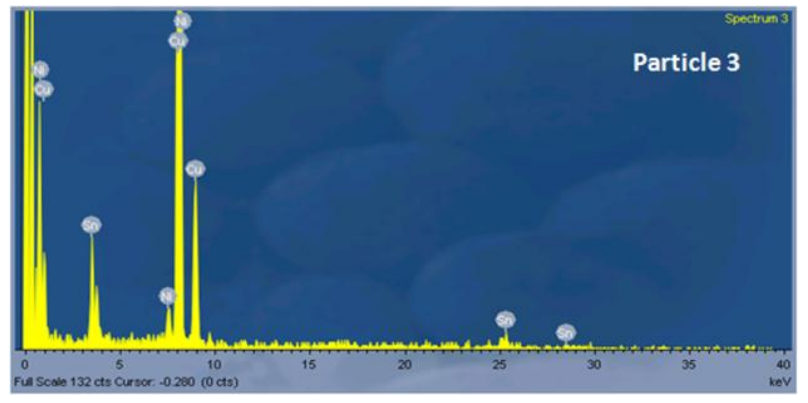




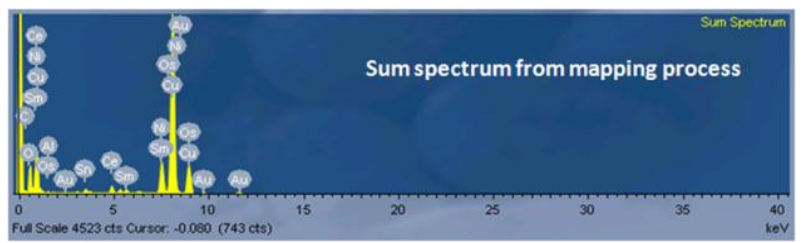




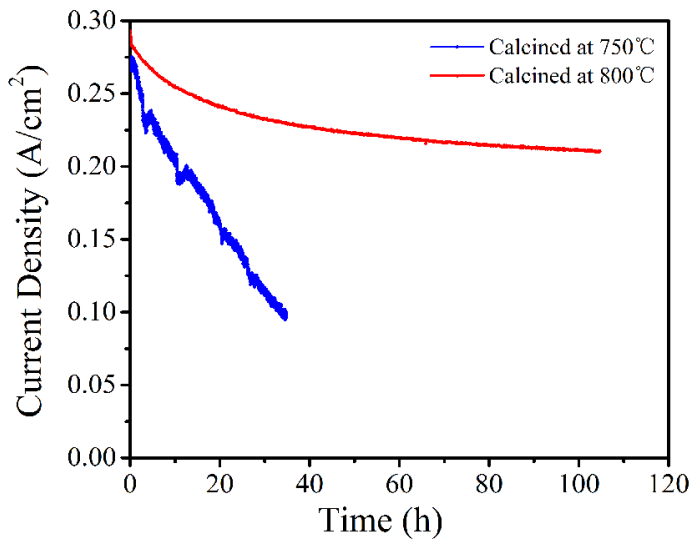




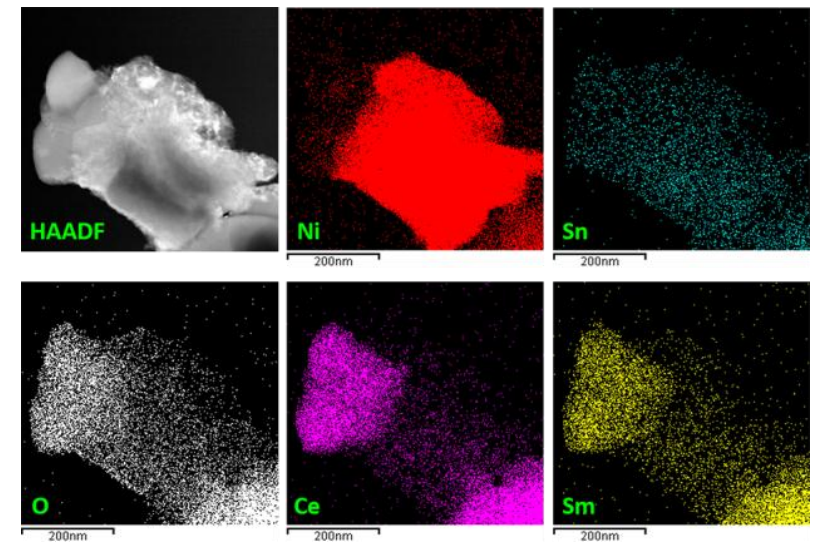




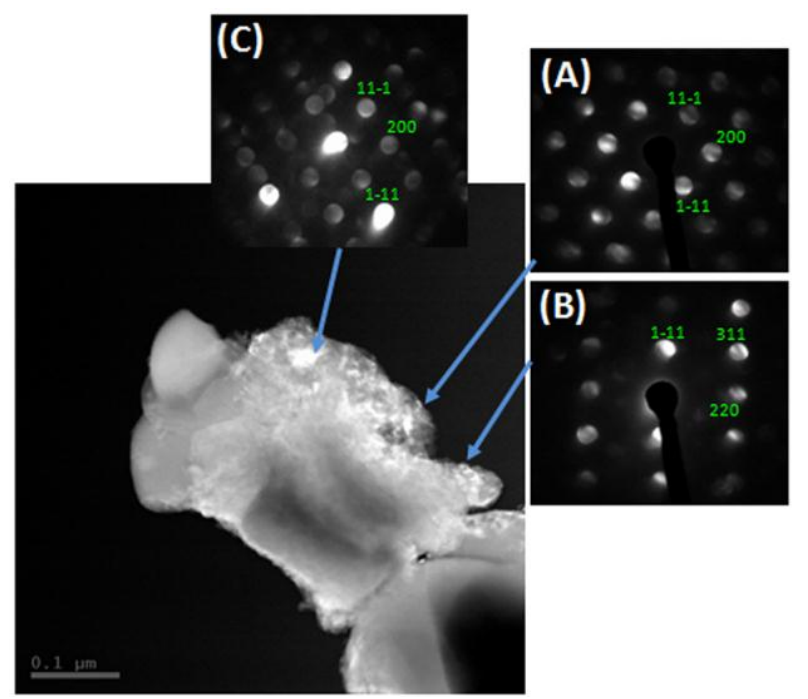

